\title{
Joan Hoff, A Faustian Foreign Policy from Woodrow Wilson to George W. Bush: Dreams of Perfectibility (New York: Cambridge University Press, 2008).
}

Rylan Kafara, University of Alberta

When American President Barack Obama was awarded the Nobel Peace Prize in late 2009, many perceived the prize as an endorsement from the international community. Such a symbolic vote of confidence was also seen as a gesture against Obama's predecessor, George W. Bush. Indeed, an editorial in The New York Times on October 9, 2009 related that "certainly, the prize is a (barely) implicit condemnation of Mr. Bush's presidency. But countering the ill will Mr. Bush created around the world is one of Mr. Obama's great achievements in less than nine months in office. Mr. Obama's willingness to respect and work with other nations is another." 1

The notion that Bush created "ill will" towards America and was willing to act unilaterally rather than foster global support is a point addressed by Joan Hoff on numerous occasions in her work A Faustian Foreign Policy. Hoff is a Research Professor of History at Montana State University in Bozeman and has written multiple monographs on twentieth-century American history, especially relating to women's legal issues, presidencies, and foreign policy. Focusing on the latter two subjects, A Faustian Foreign Policy traces the history of the American presidency from Woodrow Wilson to George W. Bush

1 The New York Times, “The Peace Prize,” October 9, 2009.

Past Imperfect

16 (2010) | @ | ISSN 1711-053X | elSSN 1718-4487 
in an attempt to show that Bush's actions were not in fact unique, but instead part of a foreign policy tradition based upon a combination of American exceptionalism and self-interest. Many works on American foreign policy share the interesting tendency to present historical issues through the lenses of their own time periods; scholars writing in this field often first show how historical circumstance has led to the contemporary political environment, and then make predictions about future political events. Examples of such works range from Ronald Steel's détente-era Pax Americana to the more recent Colossus: The Rise and Fall of the American Empire by Niall Ferguson. Both Steel and Ferguson portray America as an empire and then weigh in on this designation's implications for the country and the world at the time each was written. Hoff's work, certainly, follows in a similar vein. The author fits contemporary events into a larger historical tradition that she argues is implicit in American foreign policy behavior. She maintains that the actions of the United States taken after the attacks on September 11, 2001 were part of a pattern based on a "refusal to honor international ethical norms," and that "for most of the twentieth century America flaunted its exceptionalism as it practiced independent internationalism" (pp. 11, 21). This trend, Hoff contends, "could amount to a legacy of bloodshed exceeding that of the twentieth century," if not stopped by "current and future American leaders" (p. 203).

A well-written, well-researched and engaging monograph, A Faustian Foreign Policy follows an already welltrodden revisionist view of American foreign policy up to the end of the Cold War. It then extends this view into the twilight of the Bush presidency. It purports that policymakers in the United 
States, working under the guise of the early American founding myths, participated in "Faustian bargains," or strategies that were in direct contention with the ideals that the United States was supposed to embody. Such tactics undermined American influence on the global stage, and continued to do so while Hoff was writing. The book suffers from occasionally one-sided and predictable arguments, but Hoff takes a strong stand on numerous contentious issues, from the impact of neoconservatives have had on United States policy-making since the Nixon administration, to the limits on presidential power. As with previous books on the history of American foreign policy that also critique the contemporary political climate, A Faustian Foreign Policy will no doubt give future historians insight into the academic debates that occurred as the Bush presidency came to an end.

In the introduction, Hoff explicitly explains her intentions in writing A Faustian Foreign Policy. Her main argument is that throughout American history, following the country's revolution against England to the present and most especially during the Cold War, "the United States entered into a number of Faustian bargains and deceived the American public about them because ideological victory and/or control of resources became more important than either ethical or humanitarian principles" (p. 14). It was by defying these principles that Hoff believes deals with the devil were made. Political gains and an assurance of access to resources were taken in exchange for a loss of integrity. Two major themes guide this argument throughout the work, the first being what Hoff refers to as "the evolutionary relationship between the power of the United States and the power of the president" (p. 8). Hoff categorizes leaders from George 
Washington through Calvin Coolidge as "the premodern presidents," whose powers as commander-in-chief were largely kept in check by Congress. The evolutionary process Hoff refers to is the increased ability of the subsequent presidents to act without approval from Congress in diplomatic matters. Hoff argues that the administrations of Herbert Hoover through Ronald Reagan were "the modern presidencies," signifying an era in which congressional diplomatic power waned. While the Senate, for example, stopped Wilson's efforts to have America join the League of Nations, the modern presidents were able to avoid such difficulties. By the time of "the imponderable presidents" beginning with George H. W. Bush, American leaders were able to drive diplomacy with far less congressional interference (p. 32). ${ }^{2}$

The second theme of $A$ Faustian Foreign Policy is also an evolutionary one, in this case showing the progression of the mythical view of America as not simply unique, but as an exceptional nation. Hoff places the origin of this myth of American exceptionalism, as many other scholars have, with John Winthrop, who travelled with a group of wealthy Puritans to the New World in 1630. Upon arriving, Winthrop delivered a sermon regarded as the beginning of the "city on the hill" myth, where the United States is seen as the "New Jerusalem" and a guiding example for the rest of the world. Hoff traces this myth through the subsequent centuries, identifying it as the foundational doctrine of United States policy through the notion

\footnotetext{
2 For Hoff, "imponderable" means that because of presidential candidates' hiding behind a public image created to garner votes, "it has become next to impossible to discern with any accuracy the true personality, character, or future policies of those running for the highest office in the land" (p. 115).

Past Imperfect

16 (2010) | @ | ISSN 1711-053X | elSSN 1718-4487
} 
of Manifest Destiny, the Monroe Doctrine and Good Neighbor Policy, during the Cold War and up to the aftermath of the September 11, 2001 attacks and the ensuing War on Terror (pp. 3-4).

These themes in Hoff's work are intended to show that although America depicts itself as exceptional and an example to be followed, the country's actions have done much to undermine the "city on the hill" myth. As the book's title suggests, Hoff makes an analogy to Faust, a character from German legend who, in an effort to gain further wisdom and power, strikes a bargain with the devil's agent Mephistopheles at the price of his soul. Hoff asserts that in the examples above, especially from the early twentieth century to the War on Terror, the American government has been making deals with the devil in sharp disparity to its supposed myth of exceptionalism. Indeed, Hoff claims "Faust's relationship to Mephistopheles is emblematic of the ways the United States has conducted its foreign policy from 1920 to 2007 " (p. 2). To prove this assertion, she goes to great lengths to show the connection between presidential power, unethical practices, and the formidable power of myths in American foreign policy (p. 62).

At times, Hoff's endeavor to illustrate these connections actually lessens the impact of her ideas. For instance, near the conclusion of the first chapter, "The United States Forms and Refines Its Diplomacy," Hoff explains the reasons, in her view, for Wilson's policy of unilateral intervention in Latin America before the First World War. In the final paragraph of the discussion, she links this practice with Cold War policy and finally the George W. Bush administration's actions in the Middle East. This "connect the dots technique" implies that many of her specific points 
concerning Wilson's policies are also true of actions taken under Bush in the twenty-first century. Here Hoff is attempting to show how the Monroe Doctrine remained a guiding principle from Wilson to George W. Bush, but in doing so her depiction of the international arena becomes oversimplified. Hoff's technique seems to disregard the fluid and dynamic nature of the global environment in which the United States took action, and the constantly changing character of the international arena over the past century. Hoff repeats this formula in several other chapters, and the reader soon comes to expect that whatever historical point she is discussing will soon be linked to contemporary events. Although this is a straightforward way to conclude a discussion, it sometimes dangerously overstates the parallels between historical and present-day events.

While this formulaic approach is apparent from the first chapter, so is Hoff's strength as a biographer. As the author of works such as Herbert Hoover, Forgotten Progressive, Hoff has biographical expertise that shines through in her depiction of Woodrow Wilson's life and how his upbringing influenced his later policies. Her narrative style flows well and is not marred by an overabundance of unnecessary quotations as in other parts of the work. She also applies this flowing style to narratives of important events. Hoff's explanation of the Armenian genocide, for example, leaves the reader with a strong understanding of the tragedy. However, in a viewpoint very much in line with the themes of the work, the explanation also relates Hoff's opinion of who was at fault. Unsurprisingly, her discussion of the genocide is included in the section entitled, "Wilson as Armenia's Only Hope." 
Hoff's opinions come through very strongly later in the book as well. She lays the blame for the end of détente completely on the neo-conservatives in the Republican Party, asserting that "within ten years they had so damaged the reputation of détente, often with specious intelligence and fear propaganda, that they successfully turned the Soviet Union into the 'evil empire'” (p. 126). Analysis of actions taken by the Soviet Union, such as the 1979 invasion of Afghanistan, is disregarded in Hoff's narrative. Unfortunately, in this case such an approach makes Hoff appear quite biased because the reader is presented with only one side of the story, and other possible explanations are excluded from the discourse. Another example is the explanation of the invasion of Iraq in 2003, in which, in her opinion, "the United States again implicitly asserted its right to the world's most precious resource under the pretense of fighting a war on terrorism, eliminating weapons of mass destruction, and regime change" (p. 13). Reducing the invasion to a single reason seems shortsighted, especially since in countering, for example, the contention that Ronald Reagan single-handedly won the Cold War, Hoff offers a complicated explanation that cites a variety of complex factors (p. 131). By limiting the scope of her argument, as in the case of the invasion of Iraq, Hoff leaves the reader with the impression that she begins with ideologically motivated assumptions about events and issues and then looks for ways to support those claims, rather than forming an opinion after she has weighed all the options and evidence.

Hoff also takes a very one-sided approach in her analysis of Faustian bargains, especially when examining the Cold War. She argues that events ranging from the 1953 coup in Iran and 
the 1959 coup in Iraq, through the Gulf of Tonkin Incident to the Iran-Contra affair and the funding of the mujahidin in Afghanistan, are examples of how the United States' meddling in international affairs led to future problems. Referred to by Hoff as political "blowbacks," these later consequences were much worse than the original difficulties. What is disconcerting about this line of thinking is that it disregards, apart from United States interference, potential foreign factors that could have affected the outcomes of these events. Potential domestic factors are excluded as well. Moreover, United States interference could have led to any number of potential results (p. 123). Instead, Hoff seems to imply that a blowback was inevitable each time the United States entered into a Faustian bargain.

While Hoff intends to show the arrogance of American exceptionalism, in doing so she may herself be guilty of giving America's influence too much credit in its impact on global events. In cases where the United States did play a role, as in Afghanistan, she implies that had America not intervened, events would have turned out differently, but she does not explain why American meddling was the decisive factor. Also, Hoff cites instances where, if American leaders had intervened, such as with Wilson in Armenia, unilateral action would have been not only acceptable but beneficial (pp. 54-55, 123). Perhaps Hoff believes in another kind of American exceptionalism, in which the American government always has the power to tilt the balance of international affairs in any direction it chooses. This may be true in many cases, but it seems that to Hoff the United States only intervenes when it should not, and holds back when it should use its power. This perspective adds another devilish tone to A Faustian Foreign Policy, in that it places, however 
unintentionally, a "damned if you do, damned if you don't" framework on the book. Furthermore, Hoff's lack of empathy with the Faustian policymakers gives the impression that these decisions to make deals with the devil were committed as consciously as Faust's. It also imbues the policymakers with either nefarious intent or surprising naivety. No consideration is given to the possibility that perhaps those actually involved in making these policies, acting without the benefit of hindsight, made what they believed were the best decisions at the time, decisions that were not intended as Faustian bargains.

Still, what Hoff does give consideration to is a great deal of the existing literature in American foreign policy. She cites numerous popular authors, historians and political scientists, and includes an extensive notes section in her work. One glaring shortfall, however, is the absence of Steel's Pax Americana. Although she mentions the term Pax Americana throughout the narrative, Hoff's book could have benefited from incorporating Steel's monograph, rather than simply mentioning his name and citing a review he published of a Wilson biography (p. 9). ${ }^{3}$ Hoff apparently knows which historians to mention, but her historiographical approach in writing the work was not as rigorous and well-rounded as possible. Her reference to Niall Ferguson illuminates deficiencies as well. She directly mentions Ferguson when his description of the American empire fits her own, but when she disagrees with him by refuting a direct quotation from Colossus, she refers to his argument as something "others think" rather than specifically mentioning him by name (p. 17).

${ }^{3}$ See Ronald Steel, Pax Americana (New York: Viking, 1967).

Past Imperfect

16 (2010) | @ | ISSN 1711-053X | elSSN 1718-4487 
The argument that Hoff disagrees with is the idea that the "world needs an effective liberal empire and that the United States is the best candidate for the job." ${ }^{4}$ Hoff believes that this argument will, of course, lead to more myth-making of American virtue, and she worries that this could result in "endless war in the name of peace reminiscent of George Orwell's Newspeak" ( $p$. 17). While Hoff disregards Ferguson's argument by fitting it into her myth-making framework and then alluding to 1984, Ferguson supports his words with a persuasive explanation of why he believes the world needs the United States to be a liberal empire. ${ }^{5}$ Both authors have written books with broad appeal that blend together history, political science and sweeping opinion, but Ferguson is able to impart much more convincing and wellformed support for his arguments. Indeed, Hoff's point here is particularly problematic in light of other recent studies that point toward the world being a far safer and more peaceful place since the end of the Cold War. In the article "Welcome to World Peace," Neil Englehart and Charles Kurzman argue that, as of 2006, the contemporary "interlude of world peace [was] the culmination of a steady decline in interstate war in the aftermath of the Cold War," and that "equally dramatic [was] the decline in the number of civil wars." Furthermore, by drawing on statistical

${ }^{4}$ Niall Ferguson, Colussus: The Rise and Fall of the American Empire (New York: Penguin, 2004), 301.

5 Ferguson supports his claim by discussing the success of economic globalization, the lack of political and legal institutions in other countries, and the tendency for some states, "through either weakness or malice, [to] encourage terrorist organizations committed to wrecking a liberal world order" (pp. 301-302).

Past Imperfect

16 (2010) | @ | ISSN 1711-053X | elSSN 1718-4487 
data the authors contend that the reasons for this decline are unlikely to disappear in the near future. ${ }^{6}$

In the Cold War and post Cold War chapters, Hoff develops a theory that United States foreign policy has been largely shaped by neo-conservatives, beginning in the Richard Nixon administration and culminating during the tenure of George W. Bush. To do this she draws on her earlier work, Nixon Reconsidered, and argues that Nixon suffered a backlash from a group of radical conservatives during his term in office due to his conciliatory policies towards the USSR and China. Rather than helping Nixon to promote détente, these "new-Jacobins," who included Elmo Zumwalt, Richard Cheney, James Schlesinger, Admiral Thomas Moorer and Donald Rumsfeld, undermined Nixon's efforts and ultimately supported his resignation ( $\mathrm{p}$. 125). ${ }^{7}$ Hoff claims that "Watergate marked the beginning of the end of Republican centrism and opened the door for radical conservatives to dominate the Republican Party" (p. 126).

Hoff's analysis of the neo-conservative movement within the Republican Party may be her best attempt to weave together the major themes of $A$ Faustian Foreign Policy and prove her argument that there is a discrepancy between what the public is told and what ends American foreign policymakers are really

\footnotetext{
${ }^{6}$ Neil Englehart and Charles Kurzman, "Welcome to World Peace," Special Forces 84 (2006): 1957-67. This decline is also supported by Lotta Harloom, Stina Högbladh, and Peter Wallensteen, "Armed Conflict and Peace Agreements," Journal of Peace Research 43 (2006): 617-31.

7 That said, Nixon was forced to resign due to his criminal activity coming to light, and most of the country supported his resignation. It could be that Hoff is conflating domestic political opportunism with genuine ideological opposition. However, for an interesting and more detailed version of Hoff's account of the Nixon administration and neo-conservatives, see her online article "The Nixon Story You Never Heard," Counterpunch 7 January 2002. http://www.counterpunch.org/hoff1.html. 
trying to achieve. The rise of the neo-conservatives is outlined through their varying degrees of influence during the Reagan, George H. W. Bush, Clinton, and George W. Bush administrations. It is in the last of these that neo-conservatives such as Rumsfeld were able to exercise their ideological muscles and act upon their "blueprint for U.S. world domination" (p. 139). ${ }^{8}$ This plan included the removal of Saddam Hussein, a regime change that neo-conservatives, including Paul Wolfowitz and John Bolton, among others, had been pushing for since 1998. ${ }^{9}$ What they had been waiting for in order for this and other changes to occur, Hoff asserts by using the words of a neo-conservative think tank report, was a "catastrophic and catalyzing event like a New Pearl Harbor" (pp. 139, 241). ${ }^{10}$ One can follow the reasoning that neoconservatives might have seen the need for a "New Pearl Harbor" to occur in order to justify regime change to the American public. However, that does not mean they would have considered the September 11, 2001 attacks "heaven-sent" (p. 139). Nevertheless, Hoff makes this claim, and also slips snide comments into her narrative insulting the intelligence of George

${ }^{8}$ Hoff asserts it was during Reagan's first term and Bush's tenure following September 11, 2001 that the neo-conservatives were able to exert the most real influence on policy (p. 125).

${ }^{9}$ Hoff relates that "at the beginning of 1998, Rumsfeld, Wolfowitz, Feith, Perle, Sven Kraemer, and William Kristol, along with thirty-four neo-con members of the committee for Peace and Security in the Gulf (CPSG), signed an open letter to Clinton insisting that regime change in Iraq 'needs to become the aim of American foreign policy.' This meant, they said, the removal of Saddam Hussein" (p. 139).

10 This quotation comes from "Rebuilding American's Defenses," a ninety-page report written by the Project for the New American Century (PNAC) and released in September 2000. The quotation is from a discussion of a transformation of the American military that PNAC advocated. "The process of transformation, even if it brings revolutionary change, is likely to be a long one, absent some catastrophic and catalyzing event like a new Pearl Harbor." The quotation is on page 63 of the pdf version, and the report can be found at http://newamericancentury.org/RebuildingAmericasDefenses.pdf.

Past Imperfect 16 (2010) | @ | ISSN 1711-053X | elSSN 1718-4487 
W Bush (p. 172). This is unfortunate. Vilifying the neoconservatives and making light of Bush's persona are extremely clichéd, and without thorough and measured evaluation they also undermine what would otherwise be a completely legitimate argument. ${ }^{11}$

The culmination of A Faustian Foreign Policy is Hoff's discussion of the Bush Doctrine. Hoff claims that the Bush Doctrine is not a new twist in American foreign policy behavior because of its unilateralism or preemptive actions, but "is new only to the degree that it symbolizes a pathological imbalance between the presumed universality of American ideals and the country's actual national security interests that dwarfs previous such periodic imbalances that took place during the Cold War" (p. 170). To Hoff, these imbalances are driven by the neoconservative agenda. At the time of writing, Hoff still held out hope that "Bush [could] extract himself from the unethical and increasingly inefficient tentacles of the neo-conservatives." Otherwise, Hoff claims, Bush will be "a man who set in motion an endless war and sectarian violence throughout the Middle East...while claiming to do God's work" (p. 203). Here Hoff brings the analysis back full circle to her earlier discussion of Winthrop and the "city on the hill" myth, showing that the Iraq invasion was in line with tradition of American exceptionalism. For Hoff, the United States' actions in the Middle East following September 11, 2001 were the culminating instance of American mythmaking and unilateral action, and Hoff fears that remaining on

\footnotetext{
11 This approach hardly appeals to readers from a range of ideological perspectives, and may shed light on the book's intended audience: people who already agree with Hoff's assertions and need little further convincing. 
such a course will embroil America in a never-ending, unwinnable war.

Written in 2007, A Faustian Foreign Policy is a product of its era. Just as Steel held out hope in 1967 that détente would persist, and Ferguson argued in 2004 that good could still come out of the invasion of Iraq, Hoff takes an admirable stand by insisting that the United States "needs leaders who can see beyond the limits of the myth of American exceptionalism," and that "'masquerading as a force for good' must at long last be exposed" (p. 203). Unfortunately, the foundation that Hoff builds to support this stance is not very strong, and although even as she was writing a schism developed between the president and the new-Jacobins, the contemporary reader of this book review knows that Bush did not completely untangle himself from the neo-conservative web. The reader does not yet know, however, what will ultimately come of the gesture of support given to Obama with the Nobel Peace Prize. In the meantime, one can only hope it will not somehow be looked back upon as yet another Faustian bargain. 